\title{
Prolegomena k projektu Anglická divadelní kultura 1660-1737
}

\author{
Filip Krajník, Pavel Drábek, David Drozd, Anna Mikyšková, \\ Klára Škrobánková
}

\begin{abstract}
Divadlo období restaurace, tedy anglické divadlo doby po znovunastolení Stuartovců na anglický trůn roku 1660, stálo vždy poněkud ve stínu anglického renesančního divadla, a to jak v očích moderních badatelů, tak divadelní praxe, potažmo diváků a čtenářů. $\mathrm{V}$ posledních několika desetiletích ovšem divadelní i literární historie o tuto epochu zaznamenaly zvýšený zájem a především v kontextu anglo-americké akademické sféry se anglické restaurační divadlo objevuje jako stále častější předmět výzkumu. Oblasti současného badatelského zájmu o restaurační divadlo můžeme rozdělit do čtyř hlavních proudů:
\end{abstract} (1) politický a společenský kontext divadla; (2) divadlo v souvislosti s problematikou tř́inní, rasovou, genderovou a sexualitní; (3) historická divadelní praxe, architektura a jevištní technika; a (4) tematické sondy, jako jsou životopisy herců a dramatiků, žánrové studie, recepční analýzy či studie mezinárodních kulturních vlivů $\mathrm{v}$ této době. Zatím posledním zevrubným počinem mapujícím anglické divadlo restauračního období je 4. svazek kompendia A Cultural History of Theatre s názvem A Cultural History of Theatre in the Age of Enlightenment $\mathrm{v}$ redakci Mechele Leonové (Methuen 2017).

Španělské a francouzské divadlo této doby je v české teatrologické literatuře alespoň zčásti zpracováno díky monografiím Vladimíra Mikeše Divadlo zlatého špa- nělského věku (AMU 1995, 2013) a Divadlo francouzského baroka (AMU 2001). Kritické pojednání anglického restauračního divadla v českém prostředí však zatím schází. Česky psaná odborná či populárně naučná literatura o tomto období se omezuje na kusé části přehledových studií, a to bud' v literatuře překladové, jako jsou Craigovy Dëjiny anglické literatury (česky SNKLU 1963) či Brockettovy Déjiny divadla (česky NLN 2008), nebo jako původní dílo, jakým byly Stř́ibrného Dějiny anglické literatury (Academia 1987). Přestože se během minulého a tohoto století několik významných restauračních her dočkalo českého překladu či adaptace - naposledy Gayova Žebrácká opera, uvedená v březnu 2019 Slezským divadlem v Opavě v novém překladu Jiř́ho Záviše -, jejich inscenace bývají v českém prostředí spíše výjimkou. Do češtiny byla dosud přeložena zhruba jen desítka restauračních dramat a povětšinou jsou tyto překlady přinejmenším půl století staré, tedy v divadle málo použitelné. Mezi přeloženými hrami pak chybí nejen díla, která jsou běžně pokládána za kanonická, ale samozřejmě i hry, které by dotvořily plastičtější obraz anglické divadelní kultury tohoto období.

Za finanční podpory Grantové agentury ČR pracuje od 1. ledna 2019 při Katedře divadelních studií FF MU v Brně badatelský tým pod vedením anglisty, shakespearologa, literárního historika a překladatele 
Filipa Krajníka na projektu mapujícím anglickou divadelní kulturu období restaurace a počátku 18. století - prvním českém, a patrně i středoevropském, projektu svého druhu. Ambice projektu lze shrnout do několika bodů či „pilírůü:

(1) Vícežánrový výzkum anglického restauračního divadla, studující tuto kulturu nejen prizmatem stěžejních dramatických žánrů, jakými byly manýristické komedie či historické tragédie, ale také s ohledem na méně probádané soudobé formy, jako byly populární šarády („drolly“ či ,jigy“), lidové balady, loutkové divadlo, hudební divadlo, balet, pantomima či smíšené žánry.

(2) Transnacionální výzkum restauračního divadla nejen z pohledu vývoje anglické národní divadelní a literární kultury, ale jako fenoménu, který byl součástí širší, mezinárodní divadelní kultury a tradice, v níž se mísily anglické vlivy s prvky kontinentálními (německými, španělskými, italskými, francouzskými a jinými), které zásadním zpo̊sobem určovaly dobovou dramaturgii.

(3) Výzkum zaměřený na překlad dramatických textů jako translatologický, historiografický a divadelně praktický problém. Projekt pilotně testuje nový koncept překladu her, pracovně nazvaný „dramaturgický překlad“, který je založený na úzké spolupráci mezi překladatelem, literárním či divadelním historikem, dramaturgem a profesionálními herci, na jejímž konci bude stát sdělný text, který bude co možná účinně zprostředkovávat divadelní potenciál předlohy možným inscenátorům. Dramaturgický překlad je tak metodou, která reflektuje nejen původní divadelní kulturu, ale také rozmanitost českého divadelního jazyka dneška, a pokouší se řešit problematiku zprostředkování historické divadelnosti.

Výstupy projektu Anglická divadelni kultura 1660-1737 můžeme rozdělit na ryze badatelské a divadelně-populární. Mezi první se budou řadit odborné studie o restauračním divadle, přednesené na mezinárodních konferencích či publikované ve specializovaných akademických časopisech: pro rok 2020 počítáme se zvláštním číslem časopisu Brno Studies in English, pro rok 2021 se zvláštním číslem Theatralii. Do obou periodik vedle členů řešitelského týmu přispějí také přizvaní spolupracovníci z řad domácí i zahraniční akademické obce. Druhou skupinu bude tvořit zejména antologie, rozvržená momentálně do tří svazků, obsahující restaurační hry přeložené metodou dramaturgického překladu, které spolu s kontextovými studiemi vypracovanými členy řešitelského týmu poprvé českému čtenáři představí anglické divadlo období restaurace v ucelené, byt přirozeně selektivní podobě. Podobu antologie inspirovalo trojsvazkové Alžbětinské divadlo v redakci Aloise Bejblíka, Jaroslava Hornáta a Milana Lukeše (Odeon 1978, 1980, 1985). Antologii doplní odborná monografie o anglickém restauračním divadle, která bude vycházet $\mathrm{z}$ tradice zahraničního výzkumu této problematiky i badatelských výsledků zde představovaného projektu. Vydání antologie i monografie je naplánováno na rok 2021/22 v brněnském nakladatelství Větrné mlýny.

Mimo tyto stanovené cíle sleduje projekt několik ambicí, které přesahují jeho časově omezené trvání. Jednou z nich je posílení komunity mladých badatelů, kteří se zabývají raně novověkým anglickým divadlem a literaturou. Členkami užšího 
badatelského týmu jsou doktorandka na Katedře anglistiky a amerikanistiky $\mathrm{FF}$ MU Anna Mikyšková, jejímž výzkumným zájmem jsou nekanonické žánry restauračního divadla a zejména anglicko-německá kulturní výměna v 16. a 17. století, a doktorandka na Katedře divadelních studií FF MU Klára Škrobánková, která se věnuje anglickému lidovému divadlu období renesance a kontinentálnímu hudebnímu divadlu období baroka. Externí spolupracovnicí projektu je Kristýna Janská, doktorandka na Ústavu anglofonních literatur a kultur FF UK v Praze, jejíž oblastí zájmu je politický kontext restauračního divadla. V souvislosti s badatelskými zájmy jednotlivých členů týmu vzniká i několik diplomových prací na témata souvisejícími s cíli projektu, jejichž poznatky mohou být zahrnuty mezi výstupy projektu či podnítit další výzkum (nejnověji magisterská práce Martiny Andrisové na Katedře anglistiky a amerikanistiky FF MU, která se zaobírá adaptacemi Shakespearova Zkroceni zlé ženy z restauračního období a 18. století). $\mathrm{V}$ českém prostředí působí jen několik málo specialistů na starší anglické divadlo, proto doufáme, že náš projekt podnítí zájem o tuto oblast a vygeneruje novou generaci badatelů, kteří ve výzkumu tohoto období budou dále pokračovat.

Druhým, možná ještě ctižádostivějším záměrem projektu je propojení akademického, divadelního a překladatelského prostředí a vytvoření nové generace překladatelů (nejen) starších anglických her. Česká překladatelská tradice se momentálně nachází v unikátní a dosti svízelné situaci, kdy jedna generace překladatelů starších anglických her (zejména Shakespearových) již dokončila svou práci, zatímco nová o sobě dosud nenechala slyšet. Na plánované antologii restauračních her budou spolupracovat lidé z různých sfér, které spojuje zájem o překlad, divadlo a literaturu: akademici, jako jsou anglista, teatrolog a divadelník Pavel Drábek, teatrolog a dramaturg David Drozd, anglista a literární historik Filip Krajník, kteří jsou kmenovými členy výzkumného týmu, dále anglista a divadelní historik Tomáš Kačer a anglistka a literární historička Ema Jelínková; studenti anglistiky a teatrologie (Anna Mikyšková, Klára Škrobánková, Kristýna Janská); překladatelé, mezi jinými překladatelka beletrie a translatoložka Michaela Večerková, překladatel zejména literatury faktu a divadelník Jiří Petrů, či muzikálová a filmová překladatelka Alžběta Šáchová, a rozhlasoví a divadelní dramaturgové Helena Hložková, Michal Zahálka, Jan Šotkovský, Daniel Přibyl a další. Věříme, že spolupráce těchto osob a vzájemné sdílení zkušeností mezi obory položí základy nové překladatelské generaci staršího anglického dramatu, která v našem prostředí momentálně citelně chybí, a že vznikne precedens pro budoucí pevnější spolupráci divadelní, překladatelské a akademické obce.

Závěrem uved'me soupis her, jejichž překlad se objeví v plánované tř́svazkové antologii; seznam zahrnuje pouze úplné hry, nikoliv kratší či delší ukázky, které jsou rovněž plánovány:

William Davenant: The Law Against Lovers (1662), př. Anna Mikyšková, Filip Krajník George Villiers: The Rehearsal (1671), př. Pavel Drábek

John Dryden, William Davenant, Thomas Shadwell: The Tempest, or The Enchanted Island (1674), př. Klára Škrobánková, Filip Krajník, Alžběta Šáchová 
Thomas Duffett: The Mock-Tempest, or The Enchanted Castle (1674), př. Filip Krajník

William Wycherley: The Country Wife (1675), př. Michaela Večerková

George Etherege: The Man of Mode (1676), př. Jiří Petrů

Aphra Behn: The Rover (1677), př. Ema Jelínková

John Dryden: All for Love (1677), př. Michal Zahálka

Thomas Otway: The History and Fall of Caius Marius (1680), př. Filip Krajník

Thomas Otway: Venice Preserved (1682), př. Kristýna Janská

Aphra Behn: The Emperor of the Moon (1687), př. Michal Zahálka

Colley Cibber: Love’s Last Shift (1696), př̀. Pavel Drábek
Mary Pix: The Spanish Wives (1696), př. Ema Jelínková

John Vanbrugh: The Relapse (1696), př. Pavel Drábek

John Vanbrugh: The Provoked Wife (1697), př. Anna Mikyšková

George Farquhar: The Recruiting Officer (1706), př. Pavel Drábek

Susanna Centlivre: The Busybody (1709), př. Tomáš Kačer

Benjamin Griffin: Whig and Tory (1720), př. Filip Krajník

Lewis Theobald: Double Falsehood (1727), př. Filip Krajník

John Gay: The Beggar's Opera (1728), př. Klára Škrobánková, Alžběta Šáchová

George Lillo: The London Merchant (1731), př. Anna Mikyšková

Tento článek byl realizován za finanční podpory projektu Grantové agentury ČR GA19-07494S Anglická divadelní kultura 1660-1737. 